\title{
EFFECT OF USING ECHINACEA PURPUREA, NIGELLA SATIVA AND CHICORIUM INTYBUS IN DAIRY GOATS' DIET ON MILK PRODUCTION AND QUALITY: 2- EFFECT ON DIGESTIBILITY, SOME BLOOD PARAMETERS AND MILK PRODUCTION AND QUALITY
}

\author{
A.Z.El-Basiony ${ }^{1}$; H.M. Khattab ${ }^{1}$; A. M. Kholif ${ }^{2}$; Fatma I. I. Hadhoud ${ }^{2}$ and H.A. El-Alamy ${ }^{2}$ \\ ${ }^{1}$ Anim.Prod. Dept., Fac. of Agric., Ain Shams Univ., Shoubra El-Kheima, Cairo, Egypt. \\ ${ }^{2}$ Dept. of Dairy Sci., National Research Center, Dokki, Cairo, Egypt.
}

\section{SUMMARY}

\begin{abstract}
$\mathrm{T}$ wenty Damascus lactating goats weighting $29.2 \pm 1.96 \mathrm{Kg}$ LBW $(2.5-3$ years old $)$ were used in this experiment which randomly divided into five groups. Control group (G1) was fed basal diet, G2 was fed the basal diet mixed with $4 \mathrm{~g} / \mathrm{h} / \mathrm{d}$ Echinacea purpurea, G3 was fed basal diet mixed with $8 \mathrm{~g} / \mathrm{kg}$ Echinacea purpurea, G4 was fed $7.5 \mathrm{~g} / \mathrm{h} / \mathrm{d}$ Nigella sativa and G5 was fed $10 \mathrm{~g} / \mathrm{h} / \mathrm{d}$ Cichorium intybus for 98 days. The results showed that rumen parameters ( $\mathrm{pH}$ - TVFA's and ammonia) tend to increase significantly $(\mathrm{P} \leq 0.05)$ in basal diet mixed with $4 \mathrm{~g} / \mathrm{h} / \mathrm{d}$ Echinacea purpurea $(\mathrm{G} 2)$. Nutrient digestibilities (DM, OM, EE, CP and CF) tend to increase in treated groups when compared with the control group. Using medicinal plants lead to improve milk production in treated groups than control group, where the milk production values were $1345.4,1718.4,1516.8,1363.3$ and $1380.0 \mathrm{~g} / \mathrm{h} / \mathrm{d}$ for G1, G2, G3, G4 and G5, respectively. Regarding to milk composition, milk fat $\%$ in the treated groups was slightly higher than the control group, but total protein \% in milk was lower in G3, G5 and G4 compared with G2 and G1.The values of total protein percent were $2.89,2.93,2.77,2.52$ and $2.57 \%$, respectively for G1, G2, G3, G4 and G5. Using Echinacea purpurea effectively decreased somatic cells count (SCC) in G2 and G3, also adding Nigella sativa and Cichorium intybus to the lactating goats' diets tend to decrease SCC. The obtained values of SCC were 608.1, 64.3, 96.7, 179.0, and 105.2*103 CFU for G1, G2, G3, G4 and G5, respectively. Total microbial count was affected by adding Echinacea purpurea and Nigella sativa, where G2 recorded the lowest count followed by G3 then G4 (5.17, 5.18 and 5.38, respectively). Also, G2 and G3 recorded the lowest count of Staphylococci count and St. auraus count than G5, G4 and G1. The results indicated that using Echinacea purpurea, Nigella sativa and Cichorium intybus as additives in the dairy goats' diets tend to improve nutrient digestion coefficient also increase milk quantity and quality.
\end{abstract}

Keywords: Echinacea purpurea, Nigella sativa, Chicorium intybus, dairy goats and milk production.

\section{INTRODUCTION}

Recently, goats are considered an important aspect of animal production in Egypt. A large number of rural households raise goats with a herd size varying from 3 to 5 heads. These herds represent more than $90 \%$ of total goat population in Egypt. Therefore increasing productivity of goats will contribute to improve the standard of living of the rural people.

Milk is the most important food, which has a high nutritional value either been fed directly or after manufacturing processes. Most of goats' milk is used by dairy industry for cheese making to cover the little demand of the domestic market (El-Saied et al., 2003). Consumers do not only look for fresh and tasty milk or cheese, but also safe and healthy. The overuse of antibiotics in human and animals led to rapid rise in the number of bacteria strains resistant to majority of antibiotics, which makes infection harder to control (Tan et al., 2000). The withdrawal of antibiotics from animal production is the reason to seek for alternative solutions. One of these solutions is concerned with making use of the organisms own defense system. Depending on this fact, the use of officinal plants to enhance the immune system has been studied in goats.

Three major species, Echinacea purpurea, Echinacea angustifolia and Echinacea pallida, have been studied for their possible pharmacological and immunological effects (Nieri et al., 2003; Rininger et al., 2000). They contain biologically active factors such as polyphenols, polysaccharides and alkamides which stimulate the immuno system. Reklewska et al. (2004) reported a significantly lower SCC in goat's milk after the addition of Echinacea extract to the feed. Echinacea extract can stimulate mammary epithelial cell physiology and may be considered a candidate to support mammary gland activity during a 
mammogenetic and lactogenetic state. It also, effectively eliminates bacterial and fungal pathogens in vitro.

Nigella sativa (blackseed) seeds contain $40 \%$ fixed oil, a saponin (melantin) and up to $1.4 \%$ volatile oil (Chevallier, 1996). N. sativa seeds have a considerable antioxidant activity which probably related to their high phenolic content. It is also, known as an herb that possesses galactopoietics action (I.C.M.R, 1987). Galactagogues are believed to assist in the initiation, maintenance, or augmentation of milk production (Gabay, 2002 and Abascal and Yarnell, 2008).

Cichorium intybus contains saccharides, organic acid, alkaloid, triterpenes, sesquiterpenes, coumarins, ect. It has a function of lowering the blood glucose and lipid, decreasing uric acid, and hepatoprotection. Therefore, it is evacuant and appetitive with better cardiovascular effect. Furthermore, it can be sorbefacient calcium, enhancing immunity via antiallergic, antibacterial and antivirus. (Wang and Cui, 2009).

So that, this study was designed to investigate the effect of Echinacea purpurea, nigella sativa, and Cichorium intybus as additives to dairy goats' diet on milk production, milk composition, and milk content of SCC and microbes especially those affect the udder health and induce clinical or sub-clinical mastitis (Staphylococci spp. and Staphylococcus aureus).

\section{MATERIALS AND METHODS}

The experimental work was carried out in El-Fayroz farm located in El-Nobaria city, El-Behera government, and Lab of Dairy Production, Dairy Department, National Research Center, El-Dokki, Geza government. Twenty Damascus lactating goats weighting $29.2 \pm 1.96 \mathrm{Kg} \mathrm{LBW}(2.5-3$ years old $)$ were randomly divided into five groups (four goats / each) after 7 days of parturition using completely randomized block design to fed one of the experimental diets. Goats were fed individually according to recommendations of NRC (1981). The basal diet consists of berssem (Egyptian clover) and concentrate feed mixture (CFM) at the rate of 40:60 respectively. The concentrate feed mixture consisted of grounded corn $(39 \%)$, wheat bran $(5.1 \%)$, DDG $(9.12 \%)$, sun flower meal $(4.92 \%)$, minerals and vitamins mixture $(1.86 \%)$. Chemical composition of the experimental diets is shown in Table (1).

Table (1). Chemical composition of the experimental diets (on DM, basis).

\begin{tabular}{lllllllll}
\hline Item & \% DM & \% OM & \% Ash & \% Silica & \% EE & \% CP & \% CF & \% NFE \\
\hline Berssem & 93.7 & 87.6 & 12.4 & 2.40 & 7.90 & 15.6 & 41.8 & 22.3 \\
C.F.M. & 91.6 & 91.3 & 8.7 & 1.57 & 9.80 & 23.6 & 6.8 & 51.7 \\
Basal Diet & 92.4 & 89.8 & 10.2 & 1.90 & 9.0 & 20.4 & 20.8 & 39.6 \\
\hline
\end{tabular}

The experimental animals of the control group (G1) were fed on the basal diet, while those of the other groups were fed daily on the basal diet in addition to $4 \mathrm{~g}$ Echinacea purpurea / animal (G2); $8 \mathrm{~g}$ Echinacea purpurea / animal (G3); $7.5 \mathrm{~g}$ Nigella sativa / animal $\left(G_{4}\right)$ or $10 \mathrm{~g}$ cichorium intybus / animal. (G5).

Grab sample method was applied to determine nutrients digestion coefficients, where, acid insoluble ash (AIA) was used as an internal marker according to Gallup et al. (1945) and Forbes et al. (1948). Fecal grab samples were collected at 12 p.m., for three successive days every month for three months from each animal. Feed and feces samples were analyzed according to A.O.A.C. (1995) procedures. The digestion coefficient of a certain nutrient was calculated according to the following formula:

$$
\text { Digestion co-efficient }=100-\left[100 \times \frac{\% \text { indicator in feed }}{\% \text { indicator in feces }} \times \frac{\% \text { nutrient in feces }}{\% \text { nutrient in feed }}\right]
$$

Milk samples were obtained biweekly along the experimental period (98 days), where, goats were milked at 9 a.m., part of the sample was kept on $-20^{\circ} \mathrm{C}$ for microbiology test latterly, while the other part was transferred at the same day in cooling bag to determine SCC and milk composition. Chemical composition (total solids, fat, protein, solid-non-fat, lactose, ash and urea) and somatic cell count of milk samples were determined by using Bentley ${ }^{150}$ infrared milk analyzer (Bentley Instruments, Chaska, MN, 
USA) calibrated for goats' milk. Total count and staphylococci were counted in the frozen milk samples where total bacterial counts were enumerated using plate count agar medium according to APHA, (1978).

The count of Staphylococci generally and Staphylococcus aureus specially were carried out by using Barid-parker agar base medium (Barid-parker, 1962), where, a selective and diagnostic medium for the isolation and enumeration of Staphylococcus aureus were used. Staphylococci and Staphylococcus aureus were enumerated using Baird Parker agar with egg yolk according the method of Barid-parker (1962).

The data obtained was statistically analyzed by using the ANOVA procedures of SAS Institute (2004) according to procedures outlined by Snedecor and Cochran (1982). Repeated measurements for nutrients digestibility, yield and composition were used with the following models:

$$
\mathrm{Y}_{\mathrm{ijk}}=\mu+\mathrm{T}_{\mathrm{i}}+\mathrm{A}(\mathrm{T})_{\mathrm{ijk}}+\mathrm{W}_{\mathrm{j}}+(\mathrm{WT})_{\mathrm{jk}}+\mathrm{E}_{\mathrm{ijk}}
$$

Where, Yijk: observations, $\mu$ : overall mean, Ti: effect of different basal diets, Lj: effect of different levels of Echinacea purpurea, $(\mathrm{T} * \mathrm{~L}) \mathrm{ij}$ : the fixed effect of the interaction between the different basal diets and different levels of Echinacea purpurea, Eijk: experimental error. Separation among means was carried out by using Duncan multiple tests, (1955).

\section{RESULTS AND DISCUSSIONS}

\section{Nutrients Digestibility:}

Results of nutrients digestibility when using sun dried plant additives in dairy goats' diet (Table 2) showed that differences among the groups for nutrient digestibilies were significant $(\mathrm{P} \leq 0.05)$. The highest value of DM $\left(64.5 \%\right.$ ) was recorded for $\mathrm{G}_{2}$ (which fed on $4 \mathrm{~g} \mathrm{E}$. purpurea) followed by $\mathrm{G}_{3}(63.2 \%)$ which received $8 \mathrm{~g}$ E. purpurea $/ \mathrm{h} / \mathrm{d}$. While the lowest value $(59.6 \%)$ was reported for $\mathrm{G}_{1}$ (control group). The same trend was observed for the other nutrient (OM, EE, CP and NFE) digestibilities where values of nutrients digestibilies for animals fed on the basal diet supplemented with $4 \mathrm{~g}$ E. purpurea daily, were superior comparable to the other groups, followed by those fed supplemented diet with $8 \mathrm{~g}$ E. purpurea daily $\left(\mathrm{G}_{3)}\right.$. While the control group had the lowest values.

Data of Table (2) clearly indicated that using E. purpurea in both $\mathrm{G}_{2}\left(4 \mathrm{~g} \mathrm{E}\right.$. purpurea) or $\mathrm{G}_{3}(8 \mathrm{~g} E$. purpurea) significantly $(\mathrm{P} \leq 0.05)$ enhanced the entire nutrients digestibility coefficients especially in $\mathrm{G}_{2}$. This result may be due to the antioxidant activity of the polyphenolic components which a component of E. purpurea (Cervellati et al., 2002), and or to the antibacterial and antiviral effect of E. purpurea and its protectants against reactive oxygen species (Bergeron et al., 2000). Which provide a suitable environment for the growth of beneficial microflora in the rumen, therefor increasing its viability and its ability to utilize the diet ingredients and enhancing the nutrients digestibility coefficients.

Table (2). Effect of using sun dried plant additives on nutrients digestibility.

\begin{tabular}{lllllll}
\hline \multirow{2}{*}{ Item } & \multicolumn{5}{c}{ Groups } & \multirow{2}{*}{ \pm SE } \\
\cline { 2 - 6 } & $\mathrm{G}_{1}$ & $\mathrm{G}_{2}$ & $\mathrm{G}_{3}$ & $\mathrm{G}_{4}$ & $\mathrm{G}_{5}$ & \\
\hline DM digestibility & $59.6^{\mathrm{d}}$ & $64.5^{\mathrm{a}}$ & $63.2^{\mathrm{b}}$ & $61.2^{\mathrm{c}}$ & $61.7^{\mathrm{c}}$ & 0.27 \\
OM digestibility & $60.5^{\mathrm{c}}$ & $66.4^{\mathrm{a}}$ & $62.7^{\mathrm{b}}$ & $61.4^{\mathrm{cb}}$ & $62.5^{\mathrm{b}}$ & 0.46 \\
EE digestibility & $53.0^{\mathrm{c}}$ & $62.1^{\mathrm{a}}$ & $60.4^{\mathrm{b}}$ & $60.6^{\mathrm{b}}$ & $61.3^{\mathrm{b}}$ & 0.26 \\
CP digestibility & $68.7^{\mathrm{c}}$ & $74.0^{\mathrm{a}}$ & $70.5^{\mathrm{b}}$ & $68.6^{\mathrm{c}}$ & $71.2^{\mathrm{b}}$ & 0.45 \\
CF digestibility & $52.0^{\mathrm{b}}$ & $61.1^{\mathrm{a}}$ & $59.3^{\mathrm{a}}$ & $53.0^{\mathrm{b}}$ & $52.6^{\mathrm{b}}$ & 0.82 \\
NFE digestibility & $62.3^{\mathrm{c}}$ & $69.0^{\mathrm{a}}$ & $66.3^{\mathrm{b}}$ & $63.0^{\mathrm{c}}$ & $63.6^{\mathrm{c}}$ & 0.70 \\
\hline
\end{tabular}

$a, b \& c$ Means of parameters within the same row with different superscript letters are differ significantly $(P<0.05)$.

Using N.sativa in $\mathrm{G}_{4}$ as addition to the dairy goats' diet tend to increase the digestibility of the diet ingredient comparable to control group, These results are in agreement with those obtained by $\mathrm{Abo} \mathrm{El}$ Nor et al. (2007), who supposed that, Nigella sativa stimulate anaerobic fermentation of organic matter that improve efficiency of utilization of nutrients by its contain of saponins. In addition, it increased bacterial number in the rumen of lactating cows (Valdez et al., 1986; Ali et al., 2005). 


\section{El-Basiony et al.}

The results of $\mathrm{G}_{5}(10 \mathrm{~g} \mathrm{C}$. intybus $)$ showed that this group utilized the diet better than the control group in entire nutrient ingredients (DM, OM, EE, CP, CF, and NFE), which may be due to the ability of the $C$. intybus herb to purification of the digestion track from parasites that may affect the balance of the rumen environment and therefore adversely affect the process of digestion of different nutrients, (Molan et al (2003) and Athanasiadou et al. (2007).

\section{Blood serum parameters:}

Data of Table (3) showed that animals of $\mathrm{G}_{2}(4 \mathrm{~g}$ E. purpurea $)$ had the highest $(\mathrm{P}<0.05)$ total blood serum protein $(7.49 \mathrm{mg} / \mathrm{dl})$, whereas, the lowest value $(7.02 \mathrm{mg} / \mathrm{dl})$ was found in control group $\left(\mathrm{G}_{1)}\right.$. On the other hand, the data showed insignificant differences among $\mathrm{G}_{3}, \mathrm{G}_{4}$ and $\mathrm{G}_{5}$, where the obtained values were $7.40,7.27$ and 7.13, respectively. The values of serum total protein were within the normal range $(6.1-7.5 \mathrm{~g} / \mathrm{dl})$ as reported by Boyd (2011). The increase of total protein in treated groups may attribute to the increase of CP digestibility (Table 3). Youssef and Zaki (2001), Shahen et al. (2004) and Kassab (2007) reported that the increase protein digestibility might be the reason of increasing serum total protein and its fraction. In addition, the present results are in agreement with those found by El-Ekhnawy et al. (1999) and Mohamed et al. (2003) in sheep. Furthermore, the increase of serum total protein, as a result of Nigella Sativa seeds supplementation could be due to its positive effect on thyroid hormones secretion (Zanouny et al., 2013).

Animals of $\mathrm{G} 2(4 \mathrm{~g}$ E. purpurea) had slightly the highest $(\mathrm{P} \leq 0.05)$ albumin and globulin values followed by $\mathrm{G}_{3}$ (8g E. purpurea). According to Boyd (2011), the present values of serum albumin are slightly higher $(\mathrm{P} \geq 0.05)$ than the normal range $(2.3-3.6 \mathrm{~g} / \mathrm{dl})$ while values of serum globulin are within the normal range (2.7- $4.4 \mathrm{~g} / \mathrm{dl}$ ). Increasing of serum albumin of $\mathrm{G}_{2}, \mathrm{G}_{3}$ and $\mathrm{G}_{5}$ may be due to the higher organic matter and CP digestibility (Table, 2). The data clearly indicated no pathological lesion in the liver, since the liver is the main organ of serum albumin synthesis. Serum albumin has been shown to be a good indicator of nitrogen status, especially in small ruminants (Ingraham and Kapple, 1988; Gaskins et al., 1991 and Laborde et al., 1995).

Table (3). Effect of using sun dried plant additives on some blood serum parameters in dairy goats.

\begin{tabular}{|c|c|c|c|c|c|c|}
\hline \multirow{2}{*}{ Item } & \multicolumn{5}{|c|}{ Groups } & \multirow{2}{*}{$\pm \mathrm{SE}$} \\
\hline & $\mathrm{G}_{1}$ & $\mathrm{G}_{2}$ & $\mathrm{G}_{3}$ & $\mathrm{G}_{4}$ & $\mathrm{G}_{5}$ & \\
\hline Total Protein (mg/dl) & $7.02^{\mathrm{b}}$ & $7.49^{\mathrm{a}}$ & $7.40^{\mathrm{ab}}$ & $7.27^{\mathrm{ab}}$ & $7.13^{\mathrm{ab}}$ & 0.11 \\
\hline Albumin (mg/dl) & 3.71 & 3.81 & 3.76 & 3.64 & 3.63 & 0.06 \\
\hline Globulin (mg/dl) & 3.31 & 3.68 & 3.65 & 3.63 & 3.50 & 0.13 \\
\hline $\mathrm{A} / \mathrm{G}$ ratio & 1.16 & 1.05 & 1.09 & 1.02 & 1.05 & 0.06 \\
\hline Glucose (mg/dl) & 77.8 & 81.0 & 80.2 & 80.0 & 78.9 & 1.30 \\
\hline Cholesterol (mg/dl) & $185.5^{\mathrm{a}}$ & $176.9^{\mathrm{ab}}$ & $177.0^{\mathrm{ab}}$ & $175.5^{\mathrm{b}}$ & $181.6^{\mathrm{ab}}$ & 2.67 \\
\hline Triglycerides (mg/dl) & 236.5 & 241.8 & 238.2 & 239.7 & 240.3 & 1.92 \\
\hline Urea (mg/dl) & $67.6^{\mathrm{a}}$ & $65.8^{\mathrm{a}}$ & $66.2^{\mathrm{a}}$ & $59.2^{\mathrm{b}}$ & $65.1^{\mathrm{a}}$ & 1.15 \\
\hline AST (U/l) & $69.8^{\mathrm{a}}$ & $72.0^{\mathrm{a}}$ & $64.6^{\mathrm{b}}$ & $65.9^{\mathrm{b}}$ & $69.1^{\mathrm{a}}$ & 0.91 \\
\hline $\operatorname{ALT}(\mathrm{U} / \mathrm{l})$ & $63.6^{\mathrm{a}}$ & $59.1^{\mathrm{b}}$ & $61.5^{\mathrm{ab}}$ & $58.5^{\mathrm{b}}$ & $61.2^{\mathrm{ab}}$ & 1.09 \\
\hline Creatinine $(\mathrm{mg} / \mathrm{dl})$ & $2.83^{\mathrm{a}}$ & $1.51^{\mathrm{b}}$ & $1.76^{\mathrm{b}}$ & $1.69^{\mathrm{b}}$ & $1.74^{\mathrm{b}}$ & 0.09 \\
\hline
\end{tabular}

Addition of E. purpurea to goat's diet tend to improve the immune status (Table 3), where the changes of serum $\gamma$-globulin levels took the same trend as those of total protein and globulin levels, which reflects animal immune status and support the results that Echinacea extract stimulate goat's own defense system (Doaa, Teleb et al., 2009).

The increase in serum globulin concentration in $\mathrm{G}_{4}(7.5 \mathrm{~g} \mathrm{~N}$. sativa) may also due to an immuno stimulant effect of Nigella Sativa seeds. These results are in good agreement with Mohamed et al. (2003). Also, it has been reported that Nigella Sativa seeds increased thyroid hormones which led to increase the production of gammaglobulin (Sanad, 2000 and Sanad, 2010).

Data of Table (3) showed non-significant increase of the supplementation $(\mathrm{P} \geq 0.05)$ on blood serum glucose level. It ranged between $81.0 \mathrm{mg} / \mathrm{dl}$ (for $\mathrm{G}_{2}$ ) and $77.8 \mathrm{mg} / \mathrm{dl}$ ) (for $\mathrm{G}_{1}$ ). It may due to that medicinal plant seeds increase NFE digestibility. These results are in good agreement with those found by Nazar (1994) and El-Ashry et al. (2006) who reported that the mean values of blood glucose were higher in treated animals with medicinal herbs than control. Also, El-Ekhnawy et al. (1999) found that Nigella Sativa oil seed led to increase glucose concentrations in Barki ewes fed the maintenance ration supplemented with 150 and 250 g Nigella Sativa meal. On the other hand, Zanouny et al. (2013) found 
that, supplementation of Nigella Sativa seeds led to decrease $(\mathrm{P} \geq 0.05)$ glucose concentration in blood serum. Similar findings were reported by El-Saadany et al. (2008) in goat and Sanad (2000) in sheep.

It is of interest to notice that treated groups $\left(\mathrm{G}_{2}, \mathrm{G}_{3}\right.$ and $\left.\mathrm{G}_{5}\right)$ had on-significant lower blood serum cholesterol than control group, whereas, $\mathrm{G}_{4}$ recorded significantly lower value (Table 3 ). The highest level was recorded in control group $(185.5 \mathrm{mg} / \mathrm{dl})$ while the lowest one found in $\mathrm{G}_{4}(175.5 \mathrm{mg} / \mathrm{dl})$. These results are in agreement with El-Saadany et al. (2008) who worked on lactating Zaraibi goats. The decrease of cholesterol concentration as a result of Nigella Sativa seeds supplementation may be due to the high content of unsaturated fatty acids in Nigella Sativa seeds. Same results were reported by, Mostafa (1998) on dose and kids, and Randa (2007) on Zaraibi goats In addition, El-Saadany et al. (2008) reported that supplementation of Nigella Sativa seeds in the ration led to significant decrease of cholesterol concentration in blood plasma.

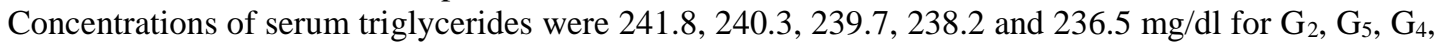
$\mathrm{G}_{3}$ and $\mathrm{G}_{1}$, respectively. The differences among the treatments were not significant.

The concentrations of blood serum urea ranged between 59.2 to $67.6 \mathrm{mg} / \mathrm{dl}$ being lower significantly for $\mathrm{G}_{4}$ tha the other groups. These values are higher than the normal range $(10-50 \mathrm{mg} / \mathrm{dl})$ as reported by Kaneko (1989); it may be related to the difference between the species. The differences among groups for AST concentration were significant $(\mathrm{P} \leq 0.05)$, where, $\mathrm{G}_{2}$ showed the highest AST level (72.0 U/I). On the other hand, there were insignificant $(P \geq 0.05)$ differences among $\mathrm{G}_{3}, \mathrm{G}_{5}, \mathrm{G}_{2}$ and $\mathrm{G}_{4}$ in blood serum ALT level (61.5, 61.2, 59.1 and 58.5 U/I, respectively). Chicory tend to decrease both AST and ALT numerically but not significantly in $\mathrm{G}_{5}$ when compared with the control group. These results were in contrast with those observed by Ahmed et al. (2008) who found that seeds of Cichorium intybus $L$. (Asteraceae) reduced the elevated levels of liver enzymes such as serum glutamate oxaloacetate transaminase (SGOT) by 52 units $/ \mathrm{ml}$; SGPT 38 units $/ \mathrm{ml}$.

Creatinine level in blood clearly presents animal kidney status, so it can be a good indicator on the animal health. Data of Table (3) showed that the control group $\left(\mathrm{G}_{1}\right)$ had significantly the highest creatinine level $(2.83 \mathrm{mg} / \mathrm{dl})$ when compared with the other groups. In same time, there was no significant differences among the treated groups

\section{Milk yield and composition:}

Data in Table (4) showed that using $4 \mathrm{~g} / \mathrm{h} / \mathrm{d}$ of Echinacea parpurea $\left(\mathrm{G}_{2}\right)$ as sun dried plant additive to dairy goats' diet tend to increase $(\mathrm{P} \leq 0.05)$ milk production and fat corrected milk (1718.4 and 1613.4 $\mathrm{g} / \mathrm{h} / \mathrm{d}$, respectively). In same time, there was no significant differences among the other groups. Mean milk production were $1516.8,1380.0,1363.3$ and $1345.4 \mathrm{~g} / \mathrm{h} / \mathrm{d}$ for $\mathrm{G}_{3}, \mathrm{G}_{5}, \mathrm{G}_{4}$ and $\mathrm{G}_{1}$, respectively. The obtained results were in harmony with those of Azadi et al. (2011) who found that daily milk production was improved after treatment with Nigella sativa extract and no significant difference was observed between the treatments. Vihan et al. (1987) found that the use of Nigella sativa medication resulted in substantial increase and sustained milk in clinical cases in goats.

The slight increase in milk production due to adding nigella sativa compared with the control group may be due to that Nigella sativa increased the secretary epithelial cells number and mammary weight (El-Komey, 1996). Also, the galactopoietics effect of Nigella sativa may be due to its estrogenic activity which was noticed by Agrawal et al. (1990).

Data in Table 4 , showed insignificant differences in $\%$ milk fat, although values of $\mathrm{G}_{2}$ slightly was the highest $(3.57 \%)$ followed by $\mathrm{G}_{5}(3.33 \%)$, but animals of contron group $\left(\mathrm{G}_{1}\right)$ recorded the lowest percentage (3.00\%). These results agreed with those found by Abo El-Nor et al. (2007) who recorded slightly increase in \% milk fat when adding Nigella sativa in buffaloes' diet.

The results of Table (4) showed, also, that there was no effect to the treatment on milk protein levels although there was slightly increase in $\mathrm{G}_{2}$ and $\mathrm{G}_{1}$ than the other groups. The values were: $2.89,2.93,2.77$, 2.77 and 2.77 for $\mathrm{G}_{1}, \mathrm{G}_{2}, \mathrm{G}_{3}, \mathrm{G}_{4}$ and $\mathrm{G}_{5}$, respectively. These results disagreed with those stated by Abo ElNor et al. (2007) who recorded slight increase in milk protein percentage when using Nigella sativa as addition to buffaloes' diet.

Data of Table 4, showed significant $(\mathrm{P} \leq 0.05)$ differences among experimental groups in \% lactose level. The values were $4.56,4.54,4.52,4.40$ and $4.35 \%$ for $\mathrm{G}_{2}, \mathrm{G}_{3}, \mathrm{G}_{5}, \mathrm{G}_{4}$ and $\mathrm{G}_{1}$, respectively. These results disagree with those found by Abo El-Nor et al. (2007) who recorded significant $(\mathrm{P} \leq 0.05)$ increase in milk lactose when adding Nigella sativa in buffaloes' diet.

Data of Table (4) showed that there were no significant differences in milk urea content. The values were 27.5, 26.9, 26.1, 22.6 and 21.4 for $\mathrm{G}_{1}, \mathrm{G}_{3}, \mathrm{G}_{2}, \mathrm{G}_{5}$ and $\mathrm{G}_{4}$, respectively. However, there were significant differences among the groups in ash, TS and SNF contents. The values of ash were 0.93, 1.05, $1.00,0.96$ and 0.92 for $\mathrm{G}_{1}, \mathrm{G}_{3}, \mathrm{G}_{2}, \mathrm{G}_{5}$ and $\mathrm{G}_{4}$, respectively. 


\section{El-Basiony et al.}

Table (4). Effect of using different sun dried plant additives on milk yield and composition.

\begin{tabular}{|c|c|c|c|c|c|c|}
\hline \multirow{2}{*}{ Item } & \multicolumn{5}{|c|}{ Groups } & \multirow{2}{*}{$\pm \mathrm{SE}$} \\
\hline & $\mathrm{G}_{1}$ & $\mathrm{G}_{2}$ & $\mathrm{G}_{3}$ & $\mathrm{G}_{4}$ & $\mathrm{G}_{5}$ & \\
\hline Production $\mathrm{g} / \mathrm{h} / \mathrm{d}$ & $1345.4^{\mathrm{b}}$ & $1718.4^{\mathrm{a}}$ & $1516.8^{\mathrm{ab}}$ & $1363.3^{b}$ & $1380.0^{\mathrm{b}}$ & 85.1 \\
\hline Fat, \% & 3.00 & 3.57 & 3.16 & 3.21 & 3.33 & 0.18 \\
\hline Total protein, $\%$ & 2.89 & 2.93 & 2.77 & 2.57 & 2.52 & 0.06 \\
\hline Lactose, $\%$ & $4.35^{c}$ & $4.56^{\mathrm{a}}$ & $4.54^{\mathrm{a}}$ & $4.40^{\mathrm{bc}}$ & $4.52^{\mathrm{ab}}$ & 0.04 \\
\hline Urea (mg/dl) & $27.5^{\mathrm{a}}$ & $26.1^{\mathrm{a}}$ & $26.9^{\mathrm{a}}$ & $21.4^{\mathrm{b}}$ & $22.6^{b}$ & 0.46 \\
\hline Ash, $\%$ & $0.93^{\mathrm{ab}}$ & $1.05^{\mathrm{a}}$ & $1.00^{\mathrm{ab}}$ & $0.96^{\mathrm{ab}}$ & $0.92^{\mathrm{b}}$ & 0.04 \\
\hline Total Solids, \% & $11.2^{\mathrm{b}}$ & $12.1^{\mathrm{a}}$ & $11.5^{\mathrm{b}}$ & $11.1^{\mathrm{b}}$ & $11.3^{\mathrm{b}}$ & 0.19 \\
\hline SNF, \% & $8.16^{\mathrm{b}}$ & $8.55^{\mathrm{a}}$ & $8.31^{\mathrm{b}}$ & $7.88^{c}$ & $7.95^{\mathrm{c}}$ & 0.06 \\
\hline $\operatorname{SCC} 10^{3}$ & $608.1^{\mathrm{a}}$ & $64.3^{c}$ & $96.7^{\mathrm{bc}}$ & $179.0^{\mathrm{b}}$ & $105.2^{\mathrm{bc}}$ & 28.8 \\
\hline SCC Log & $5.68^{\mathrm{a}}$ & $4.69^{c}$ & $4.81^{\mathrm{c}}$ & $5.02^{\mathrm{b}}$ & $4.77^{c}$ & 0.05 \\
\hline TC. (cfu) & $5.60^{\mathrm{a}}$ & $5.17^{\mathrm{c}}$ & $5.18^{c}$ & $5.38^{b}$ & $5.54^{\mathrm{a}}$ & 0.03 \\
\hline St. (cfu) & $1.50^{\mathrm{a}}$ & $0.33^{\mathrm{b}}$ & $0.42^{b}$ & $0.58^{b}$ & $0.46^{\mathrm{b}}$ & 0.20 \\
\hline St. aureus (cfu) & $0.58^{\mathrm{a}}$ & $0.00^{\mathrm{b}}$ & $0.00^{\mathrm{b}}$ & $0.04^{\mathrm{b}}$ & $0.04^{\mathrm{b}}$ & 0.11 \\
\hline
\end{tabular}

$a, b \& c$ Means of parameters within the same row with different superscript letters are differ significantly $(P<0.05)$. SCC: somatic cells count

The obtained result demonstrated significant $(\mathrm{P} \leq 0.05)$ differences in milk content of TS and SNF, where $\mathrm{G}_{2}$ recorded the highest percentage followed by $\mathrm{G}_{3}$ (12.1 and $11.5 \%$, respectively) and SNF (8.55 and $8.31 \%$, respectively). However, the lowest percentages were returned to $\mathrm{G}_{4}$ in both TS and SNF (11.1 and $7.88 \%$, respectively). Abo El-Nor et al., (2007) recorded slightly increase in SNF when adding Nigella sativa in buffaloes' diet.

Adding sun dried plant additives significantly $(\mathrm{P} \leq 0.05)$ decrease somatic cells count (SCC) in produced milk (Table 4). Using Echinacea parpurea in $\mathrm{G}_{2}$ and $\mathrm{G}_{3}$ was the most effective treatments on SCC, where the overall means for the experimental groups were 608.1, 179.0, 105.2, 96.7 and $64.3 * 10^{3}$ cfu for $\mathrm{G}_{1}, \mathrm{G}_{4}, \mathrm{G}_{5}, \mathrm{G}_{3}$ and $\mathrm{G}_{2}$, respectively. These results are in agreement with Reklewska et al. (2004) who reported that Echinacea purpurea extract reduced mammary infections and SCC in goats' milk by increasing lactofferin secretion, which is anti-bacterial, anti-viral and immuno-stimulating compound. Similar results were obtained by Doaa, Teleb et al. (2009) when used Echinacea purpurea extract in infected goats and by Azadi et al. (2011) when add the Nigella sativa to cows diets. In contrast, Dymnicka et al. (2003) observed no significant changes in milk SCC in cows given $300 \mathrm{~g} /$ animal of dried whole Echinacea purpurea plant over 3 weeks.

Data of microbial content in milk (Table 4) revealed that the highest significant $(\mathrm{P}<0.05)$ counts were recorded in the control group $\left(G_{1}, 5.60\right)$ followed by those fed on $10 \mathrm{~g} / \mathrm{h} / \mathrm{d}$ cichorium intybus $\left(\mathrm{G}_{5} .554\right)$. However, the lowest counts were found in $\mathrm{G}_{2}$ followed by $\mathrm{G}_{3}(5.17$ and $5.18 \mathrm{cfu})$.

The obtained results clearly showed that Echinacea parpurea tend to decrease staphylococci count in milk samples significantly $(P \geq 0.05)$ in $\mathrm{G}_{2}$ and $\mathrm{G}_{3}(0.33$ and $0.42 \mathrm{cfu})$, On the other hand, control group $\left(\mathrm{G}_{1}\right)$ recorded the highest staphylococci count followed by $\mathrm{G}_{4}$ then $\mathrm{G}_{5}$ (1.58, 0.58 and 0.46 , respectively). With the same trend the experimental groups differed in the St. auraus count, where Echinacea parpurea groups $\left(\mathrm{G}_{2}\right.$, and $\left.\mathrm{G}_{3}\right)$ recorded the lowest St. auraus count $(0.00 \mathrm{cfu})$ in milk samples followed by $\left(\mathrm{G}_{4}\right.$ and $\left.\mathrm{G}_{5}\right)$ which recorded $0.04 \mathrm{cfu}$ in each. The control group $\left(\mathrm{G}_{1}\right)$ differed significantly $(\mathrm{P} \leq 0.05)$ with the other groups where, $\mathrm{G}_{1}$ recorded the highest St. auraus count $(0.58 \mathrm{cfu})$.

The present results of SCC, total microbial count, Staphylococci count and St. auraus count, are in agreement with Azadi et al. (2011) who found that, the daily milk production improved and reduced the bulk milk SCC from $245,000-218,000$ cells $\mathrm{mL}^{-1}$ in the treated groups with Nigella sativa extract.

Based on the results of this be study it can concluded that adding sun dried medical plants as Echinacea purpurea, nigella sativa, and Chicorum Intybus can enhance nutrients digestibilities and milk production of dairy goats and improve dairy animal's health status by increasing the animal resistance to harmful microbes. 


\section{REFERENCES}

A.O.A.C. (1995). Official methods of analysis. 15th ed. Association of Official Analytical Chemists. Arlongton, Virginiall USA.

Abascal, K. and E. Yarnell (2008). Botanical Galactagogues, Vol. 14, pp: 288-294. Mary Ann Liebert, Inc.

Abo El-Nor, S.A.H.; H.M. Khattab; H.A. Al-Alamy; F.A. Salem and M.M. Abdou (2007). Effect of some medical plants seeds in the rations on the productive performance of lactating buffaloes. INT. j. Dairy Sci., 2 (4):348-355.

Agrawal, C.A.; Narula, D.K. Vyas and D. Jacob (1990). Effect of (Kalaunji) (Nigella sativa) on the fertility and sialic content of the reproductive organs of the male rat. Geobios, 17: 269.

Ahmed, B.; S. Khan; M.H. Masood and A.H. Siddique (2008). Anti-hepatotoxic activity of cichotyboside, a sesquiterpene glycoside from the seeds of Cichorium intybus. J Asian Nat Prod Res., 2008 MarApr; 10(3-4):223-31.

Ali, M.F.; M.S. Saleh; N.M. Eweedah and S.A. Mohmoud (2005). Effect of using chamomile (Mtrricaria chamomilla) flowers as feed additives on performance of growing lambs under desert farming system. Egypt. J. Nutr. Feeds, 8:127-137.

APHA (1978). Standard Methods for the Examination Dairy products, 12th ed. Am. Publ. Healh Assoc., New York.

Athanasiadou, S; D. Gray; D. Younie; O. Tzamaloukas; F. Jackson and I. Kyriazakis (2007). The use of chicory for parasite control in organic ewes and their lambs. , Feb; 134(Pt 2):299-307. Epub 2006 Oct 11 .

Azadi, H.G.; Nima Farzaneh; Zahra Baghestani; Azam Mohamadi and Seyed Ali Mahdavi Shahri (2011). Effect of Intramammary Injection of Nigella Sativa on Somatic Cell Count and Staphylococcus Aureus Count in Holstein Cows with S. aureus Subclinical Mastitis. American Journal of Animal and Veterinary Sciences, 6 (1):31-34.

Bergeron, C; J.F. Livesey; D.V.C. Awang; J.T. Arnason; J.B. Rana; R. Baum and W. Letchamo (2000). A quantitative HPLC method for the quality assurance of Echinacea products on the North American Market. Phytochem. Anal., 11:207-215.

Barid-parker, A.C. (1962). An improved diagnostic and selective medium for isolating coagulase positive staphylococci. J. Appl. Bacteriol., 25:12-19.

Boyd, J.W. (2011). The interpretation of serum biochemistry test results in domestic animals, In: Veterinary Clinical Pathology, Merck Sharp \& Dohme Corp., a subsidiary of Merck and Co., Inc.

Cervellati, R.; C. Renzulli; M.C. Guerra and E. Speroni (2002). Evaluation of antioxidant activity of some natural polyphenolic compounds using the Briggs-Rauscher reaction method. J. Agric. Food Chem., 50:7504-7509.

Chevallier, A. (1996). The encyclopedia of medicinal plants, Dorling Kindersley publishers, London, P: 237.

Doaa, F. Teleb; U. M. El-Saied; A.A. Sallam; Azza M. El-Baz and A.M. Hussein (2009). Effect of Using Echinacea Extract as Immuno-stimulating Additive on Milk Yield Traits, Immunity and Udder Health of Zaraibi Goats. Egyptian Journal of Sheep \& Goat Sciences, 4 (2):33-53.

Duncan (1955). Multiple range and multiple F test. Biometric, 11:1-42.

Dymnicka, M.; A. Lozicki; M. Koziorowski; J. Klupczynski; J. Micinski and A. Mscisz (2003). Effect of the addition of dried Echinacea purpurea in the diet of cows on the content of somatic cell in milk and the level of $\gamma$-globulins in blood serum of cows and calves and in colostrums. Proceedings of the XXXII Polish Academy of Sciences Committee of Animal Production Conference "Animal nutrition and safety food production". 14-15 September, Lublin, Poland. Abstract, p. 30.

El-Ashry, M.A.; N.E. El-Bordeny; H.M. Khattab and H.M. El-Sayed (2006). Effect of diets supplemented with medicinal herbs on nutrient digestibility and some blood metabolites of buffalo calves. Egypt J. Nutr. Feed, 9:179-191.

El-Ekhnawy, K.E.; A.M. Otteifa; H. Omima Ezzo and M. Hegazy (1999). Post-weaning reproductive activity of Barki ewes lambing in spring while fed Nigella Sativa oil seed meal. Assiut Vet. Med. J., 40:292.

El-Komey, A.G. (1996). Effect of black seeds (Nigella sativa) during pregnancy and lactation on mammary gland development in rat. Alex. J. Agric. Res., 41:63-74.

El-Saadany, S.A.; A.A.M. Habeeb; E.S. El-Gohary; M.M. El-Deeb and K.M. Aiad (2008). Effect of supplementation with oregano or Nigella Sativa seeds to diets of lactating Zaraibi goats on milk yield and some physiological functions during summer season. Egyptian J. Anim. Prod., 45 Suppl. Issue, Dec,:469. 


\section{El-Basiony et al.}

El-Saied, U.M.; R.E. Al-Ahwal; M.E. Ahmed; Ferial Hassan and B.M. Edrise (2003). Relationship between somatic cell counts and intramammary infection in Egyptian Zaraibi. Egyptian J. Anim. Prod., 40 (2):129-137.

Forbes, R.M. and W.P. Garrigus (1948). Application of a lignin ratio technique to the determination of the nutrient intake of grazing animals. J. Ani- mal Sci., 7:373.

Gabay, M.P. (2002). Galactagogues: medication that induce lactation. J. Hum. Lac., 18: 274-279.

Gallup, W.D.; C.S. Hobbs and H.M. Briggs (1945). The use of silica as a reference substance in digestion trials with ruminants. J. Animal Sci., 4:68.

Gaskins, H.R.; W.J. Croom, Jr; J.M. Fernandez; J.E. Van Eys; W.M. Hagler, Jr, and W.L. Johnson (1991). Metabolic responses to protein supplementation and slaframine in goats and sheep fed roughage. Small Ruminant Res., 6:73-84.

I.C.M.R. (1987). Medicinal Plants of India. Indian Council of Medical Research, New Delhi, India. Indiastat.com: http://www.indiastat.com/agricult.

Ingraham, R.H. and L.C. Kappel (1988). Metabolic profile testing. Vet. Cin. North Am. Food Pract., 4:391-411. Gaskins, H.R; W.J. Croom, Jr; J.M.

Kaneko, J.J. (1989). Clinical Biochemistry of Domestic Animals 4th ed., Academic Press, Inc., USA.

Kassab, A.Y. (2007). Effect of protected protein on productive and reproductive performance of sheep, Ph.D Thesis, Fac. of. Agric., Minia University, Egypt.

Laborde, C.J.; A.M. Chapa; D.W. Burleigh; D.J. Salgado and J.M. Femandez (1995). Effects of processing and storage on the measurement of nitrogenous compounds in ovine blood. Small Ruminant Res., 17: 59- 166.

Mohamed A.H.; B.E. El-Saidy and I.A. Seidi (2003) Influence of some medicinal plants supplementation: 1- On digestibility, nutritive values, rumen fermentation parameters in sheep. Egyptian J. Nutrition and Feeds, 6(2):139.

Molan, A.L.; A.J. Duncan, T.N. Barry, and W.C. McNabb (2003). Effects of condensed tannins and crude sesquiterpene lactones extracted from chicory on the motility of larvae of deer lungworm and gastrointestinal nematodes. Parasitol Int. Sep; 52(3):209-18.

Mostafa, A.M. (1998). Effect of using medicinal plant on goats performance, Ph. D. Thesis, Fac. of Agric., Cairo Univ., Egypt.

Nazar, F.A.A. (1994). The use of some medicinal plant as ruminal tonics of sheep. M. Sc. Thesis, Fac. Vet. Med. Moshtohor, Zagazig Univ., Egypt.

Nieri, P.; B. Adinolfi I. Morelli; M.C. Breschi; G. Simoni and E. Martinotti (2003). Genetic characterization of the three medicinal Echinacea species using RAPD analysis. Planta Med., 69:685686.

NRC (1981). Nutrient Requirements of Goats: Angora, Dairy and Meat Goats in Temperate and Tropical Countries. National Academy Press, Washington D.C

Randa, R.E. (2007). Performances of goats fed certain medical herbs with reference to milk production and its manufacture. Ph D. Thesis, Fac. of. Agric., Cairo Univ., Egypt.

Reklewska, B.; E. Bernatowicz; Z. Ryniewicz; R. Rua Pinto and K. Zdziarski (2004). Preliminary observations on the Echinacea-induced lactoferrin production in goat milk. Anim. Sci. Papers and Reports, 22 (1):17-25.

Rininger, J.A.; S. Kickner; P. Chigurupati; A. McLean and Z. Franck (2000). Immunopharmacological activity of Echinacea preparations following simulated digestion on murine macrophages and human peripheral blood mononuclear cells. J. Leukoc. Biol., 68:503-510.

Sanad, M.A. (2000). Productive performance and metabolism in Saidi ewes and their lambs fed ration containing Nigella Sativa seeds. M.Sc. Thesis, Fac. of. Agric., Assiut University, Egypt.

SAS (2004). SAS. User's Guide, Release 8.2. Inc., Cary, NC: SAS Inst.

Shahen, G.F.; A.A. Zaki and H.M. Yousef (2004). Effect of feeding level on growth, nutrient digestibility and feed efficiency of buffalo calves. Egypt. J. Nutrition and Feeds, 7(1):11.

Snedecor, G.W. and W.G. Cochran (1982). Statistical Methods. 7th ed. Iowa State Unvi. Press, Ames, Iowa, USA.

Tan, Y.T.; D.J. Tillet and I.A. Mckay (2000). Molecular strategies for overcoming antibiotic resistance in bacteria. Molecular Medicine Today, 6:309-313.

Valdez, F.R.; L.J. Bush; A.L. Gosetsch and F.N. Owens (1986). Effect of steroidal sapogenins on ruminal fermentation and on production of lactating dairy cows. J. Dairy Sci., 69:1568-1575.

Vihan, V.S. and H.S. Panwar (1987). Galactopoietics effect of Nigella sativa (kalonji) in clinical cases of agalectia in goats. Indian Vet. J., 64:347-349.

Wang, Q. and J. Cui (2009). A review on pharmic effect of chicory research and development. Zhongguo Zhong Yao Za Zhi., Sep; 34(17):2269-72. 
Youssef, M.M. and A.A. Zaki (2001). Effect of barley radical feeding on body weight gain and some physiological parameters of growing Friesian crossbred calves. Egyptian J. Nutrition and Feeds, (special Issue) 6:465.

Zanouny A.I.; A.K.I. Abd-El moty; M.A.A. El -Barody; M.T. Sallam and A.A. Abd El-Hakeam (2013). Effect of supplementation with nigella sativa seeds on some blood metabolites and reproductive performance of ossimi male lambs. Egyptian Journal of Sheep and Goat Sciences, 8(1):47-56, 2013

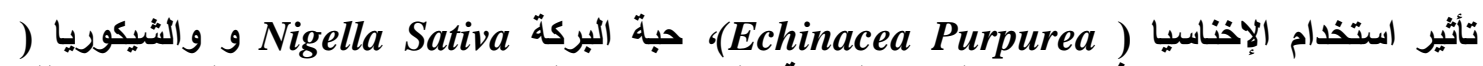 (Chicorum Intybus

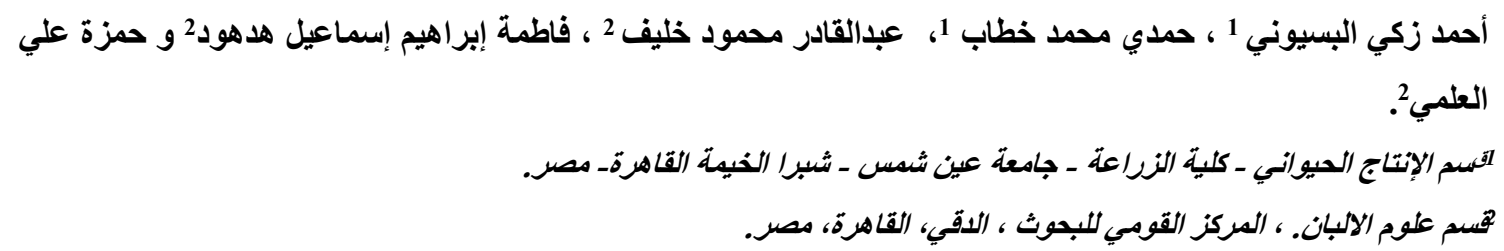

قسمت عشو ائيا عشرون من الماعز الدمشقي الحلابة عند الو لادة (منوسط وزنها 29.2 ـ 1.96 كجم ومنوسط عمر ها 2.5 - 3 سنة) إلى خمس مجمو عات لار اسة تأثنير استخدام كل من الإخناسيا، (Echinacea Purpurea)، حبة البركة على إنتاج اللبن و جودنه. حبث تم تغذية مجموعة المقارنة (Ghicorum Intybus

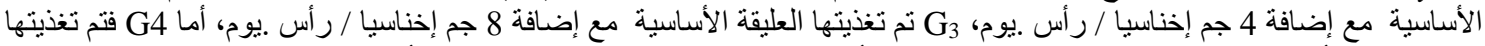

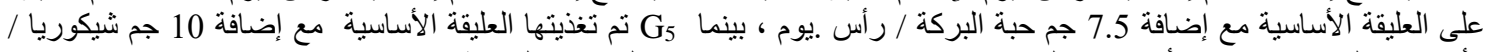

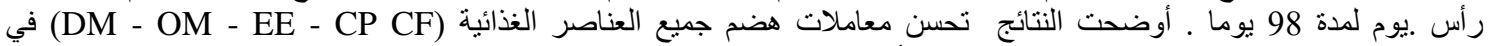

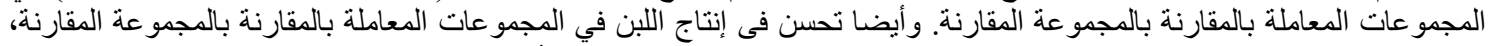

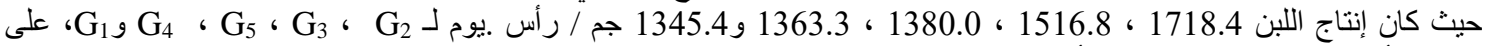

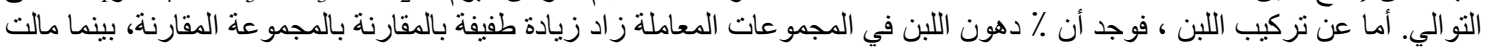

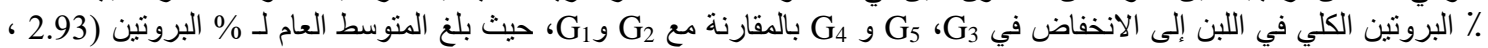

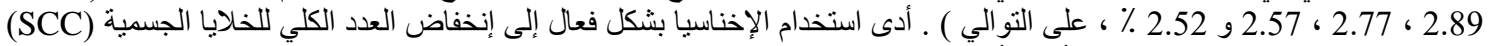

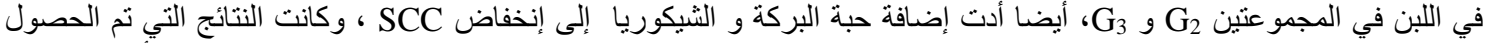

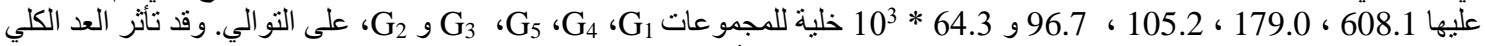

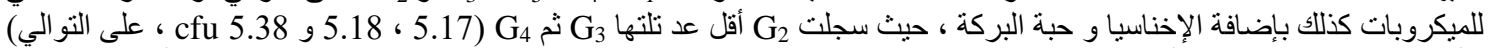

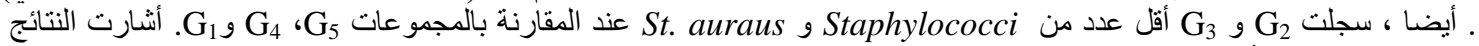

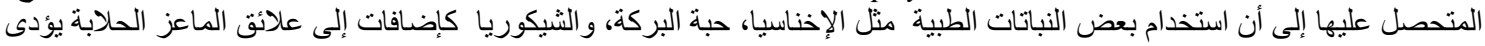
إلى تحسين معامل هضم المو اد الغذائية كما يؤدي إلى زيات الطيادة كمية اللبن المنتج ويحسن من جودنها 